\title{
Spirit Ecologies and Customary Governance in Post-conflict Timor-Leste
}

\author{
Lisa Palmer \\ University of Melbourne \\ lrpalmer@unimelb.edu.au \\ Andrew McWilliam \\ Western Sydney University \\ a.mcwilliam@westernsydney.edu.au
}

\begin{abstract}
In post-conflict Timor-Leste, the concepts of spirit ecologies and intergenerational wellbeing direct our attention to the ways in which Timorese people derive strength from house-based family networks as well as protective and productive spiritual relations with living nature. These practices of exchange resonate with a comparative body of research that has described similar 'spiritscapes' elsewhere in Southeast Asia and their relevance for social and environmental governance. Exploring the diverse ontologies of particular Timorese 'spirit ecologies' and their embedding in a concept of more-than-human 'intergenerational wellbeing', in this article we investigate the renewed significance of these 'house-based' practices for social and environmental governance in Timor-Leste. We argue that despite the challenges, multiple engagements of mutually appropriated, transgenerational debt obligations and ritually regulated forms of resource governance are emerging as cultural, and increasingly state-sanctioned, strategies aimed at rebuilding the social and environmental commons.
\end{abstract}

\section{Keywords}

spirit ecologies - intergenerational wellbeing - resource governance - ritual exchange - meshwork 
Timor-Leste's historic achievement of independence, following a generation of resistance struggle (1975-1999), came at a substantial cost. The destructive withdrawal of the Indonesian military in 1999 prefigured the collapse of the market economy and wage employment opportunities, as well as the withdrawal of all government services and much of the administrative capacity of governance as Indonesian civil servants departed en masse (Fox and Babo Soares 2000). These were inauspicious beginnings for a new nation.

In the post-independence era, officially from May 2002, the continuing challenges of social and economic recovery, the lingering effects of Indonesian military occupation, and the slow reinstatement of government services has prompted a revitalization of ancestral traditions across Timorese society. This 'return to custom' (Hicks 2008; Barnes 2011) includes, among other features, the widespread reconstruction of origin houses (uma lulik); the return of many displaced and resettled communities to their ancestral lands; a reinvigoration of social and ceremonial exchange; and a renewed attention to sacrificial rituals and ancestral spiritual authority (Myat Thu 2001; McWilliam 2008). Each of these approaches to the renewal and revitalization of social and cultural exchanges engages the co-production of custom and governance across the scale - from the micro-social dynamics of household and domestic economies to broader issues of social alliance, resource entitlements, landed authority, and collective endeavour. These 'spirit ecologies', as we interpret them, incorporate each of these realms of activity and more. They reflect local orientations to diverse forms of agency, both human and non-human, that are fundamental to the multiple tasks of keeping life going and sustaining personal and intergenerational wellbeing over time. As such, they also raise important questions about the resilience and capacity of indigenous institutions to fill the governance gap in post-conflict Timor-Leste, to restore a sociality damaged by war, and to contribute to innovative forms of environmental governance with relevance to the wider region.

In this article, we are interested in the comparative and cross-scalar possibilities of these locally relevant spirit ecologies. In particular, we are interested in the ways they can help frame relationships between people and place, and between customary approaches to nature on the one hand and national governance policies over land and waters on the other. In this regard, contemporary Timor-Leste offers an instructive Asia-Pacific experiment in nationbuilding from the ground up. A key component of this enterprise has been the introduction of so-called best-practice state management of social and environmental governance. 
However, like the experience in other parts of the world, these measures of impact frequently suffer from a critical blind spot. They overlook the interests, rights, and traditional entitlements of constituent customary communities. Consequently, they fail to consider how pre-existing bodies of knowledge, institutions, and praxis contribute to local and regional governance regimes (Jackson and Palmer 2012; Palmer 2015; Paris 2004; Zerner 2003). A case in point for Timor-Leste is the complex of locally constituted resource regulations known as tara bandu (literally 'to hang the prohibition [usually on a post]'). These customary practices are widely deployed to protect ripening crops, limit cultural burning, resolve conflicts, restrain transgressive behaviour, and even limit the inflationary post-war effects of increased ceremonial exchange of animals in life cycle events. In the light of their local purchase, these cultural practices have found favour with state institutions in recent years, but too often the nature of the traditions is elided or ignored in favour of finding ways to appropriate them for broader, state-based environmental and political ends. Conversely, we would argue that by identifying the depth and significance of customary approaches to social and environmental governance in TimorLeste (and, indeed, elsewhere), we can generate a more nuanced comparative understanding of how these practices are being mobilized to address processes of social and economic recovery and resilience in complex environments.

In our use of the term 'spirit ecologies' we are concerned with the ways in which human forms of sociality evolve alongside relations with more-than-human beings, including places in the landscape, particular animals, spirits, and the ancestral presence. We deploy the concept as a way of understanding the relational nature of personhood in Timor-Leste, and the ways in which human and more-than-human networks of reciprocal obligation and interdependency are constitutive of 'house-based' societies (McWilliam 2005). We argue that rather than reducing these spirit ecologies to the sphere of 'belief' or 'religion' they should be understood as ways of being in the world that underpin diverse modes of localized governance. In this respect the article contributes theoretically to a body of work in Southeast Asian studies that has paid renewed attention to human relations with the more-than-human environment. ${ }^{1}$ In

1 Lansing 2007; Tsintjilonis, 2004; Allerton 2013; Arnhem and Sprenger 2016. 
Timor-Leste, Bovensiepen (2015) has demonstrated how ideas of personhood are configured and emerge through relations of separation and reunification with the landscape. Similarly, Palmer (2015) has investigated human relations with water in Timor-Leste and the ways that water 'management' rituals are integral to the beliefs and practices of localized spirit ecologies. In this article, we continue the task of mapping the relationship between Timorese conceptions of personhood (Bovensiepen 2015), ancestrally constituted house communities (Fox 2011), and the complex local ecologies upon which the livelihoods and the material and spiritual wellbeing of Timorese households depend (Palmer 2015).

In tracing the effects of these spirit ecologies on modes of Timorese social and environmental governance, we recognize the contemporary significance in Timor of a broadly shared Austronesian heritage of ideas and practices around fundamental notions of connected life processes. These relational fields are expressed through a rich repertoire of what Fox (1980:333) has described as 'metaphors for living [...] encoded primarily in a pervasive binary form'. Prevalent among these customary associations are the many complex botanical metaphors of growth and renewal (trunk and tip, roots and climbing tendrils, rhizomic replication of sugar cane and bananas) and the rich spatio-temporal metaphors of journeys and well-travelled pathways (paths of origin, the wide path of alliance; see Fox 1997).

These customary ideas of life processes also resonate with the work of Tim Ingold (2011, 2012:431) and his concept of the 'meshwork', which we draw on to follow the 'material flows and formative processes' of localized spirit ecologies. According to Ingold, places in this 'meshwork' are like 'knots', from which flow a multitude of relational threads:

A house, for example, is a place where the lines of its residents are tightly knotted together. But these lines are no more contained within the house than are threads contained within a knot. Rather, they trail beyond it, only to become caught up with other lines in other places, as are threads in other knots. Together they make up what I have called the meshwork.

INGOLD 2011:149

Ingold's concept of intersecting lines and pathways through places, 'houses', and a wider ecology of things illustrates the ways that life both comes into being and is continuously becoming through exchanges between living and non-living organisms, and between cultural meanings and physical forms. In this 'meshwork' of 'things' (which may encompass state institutions and practices) across 'generations', we show how the past, present, and future can be 
experientially coeval and how the properties of 'materials' and their continuous exchanges form a continuum of life, a relational coherence that grows and is grown.

In this conceptual schema, the flow of the living meshwork is also selectively shaped by processes of resistance and separation, of an active 'holding apart' of different types of matter that constitute fundamental features of the relationship (Palmer 2018). By investigating local struggles to influence and assert agency over the more-than-human, our aim is to make visible these flows and points of resistance and separation in localized spirit ecologies and to demonstrate their relevance, as well as their generative and disabling effects for social and environmental governance in Timor-Leste.

Our approach to elucidating Timorese spirit ecologies through a meshwork of matter connects an endogenous theory of more-than-human intergenerational wellbeing'. This theory extends beyond a generalized notion of human concern for future generations and/or the environment to understandings of a more-than-human, kin-based sociality in Timor-Leste (Palmer 2015; see also Trindade 2008). Finding form in everyday practices is a way of being in the world that focuses people's attention on the need to honour, and attend to, particular pathways of connection (Strathern 2014) between human beings (the living, the dead, and the not-yet-born) and their more-than-human kin (for instance, particular species of animals, lands, and waters constituted in myth). As pathways towards wellbeing (and associated constraints on these flows), they guide people's interactions with their local spirit ecologies and announce the basis for a continuous (re)constitution of people's relations with one another and with the wider world around them. In the associated ritual and ceremonial activities, these performative practices work to 'bring forth, define, and empower social relationships' (Lansing 2007:15). To this extent, our concern in Timor-Leste is with the multiple ways that objects and artefacts, 'natural' elements, and non-human living organisms evoke meaning within relational human networks and are enrolled in the everyday, multiple tasks of keeping life going.

An account of these emerging networks and practices of environmental governance in Timor-Leste must also consider the strong influence of formal institutional religion, which exists in pluralist tension with ancestral forms of religious adherence. The historical power of the Catholic Church is highlighted by the fact that its influence overtly shapes approaches to religiosity and ritual practice, especially in urban Timorese contexts where being 'modern' has long meant being both educated and Catholic (Palmer, Barnes and Kakuma 2017; Silva 2013). Yet, to the extent that these Catholic, state and ancestral practices intersect, we contend that it is these seemingly contradictory forms of social- 
ity, relationality, and subjectivity that are inevitably and uniquely interwoven through a meshwork of practices, including religiously inflected ones. Ann Salmond makes a similar point writing on freshwater governance approaches in New Zealand. Governance there implicates a more-than-human personhood and ontological complexity with slippage both within and between Maori (indigenous) and Pakeha (settler) communities, as she notes:

[i]n these people, practices, and places, ancestral Maori concepts are active and alive, adapting to changing conditions, including various modernist assumptions about reality. The process of juxtaposition and exchange has generative effects. It makes it possible to deal creatively with competing and shifting universalisms without feeling the need for an 'eye of God' account in which only one set of propositions about reality can prevail.

SALMOND 2014:301

Having outlined our theoretical approach above, we now turn to an exploration of one particular set of Timorese spirit ecologies, highlighting the contingent, generative capacities and effects that are strongly evident in the Fataluku customary realm. We then examine the application of these generative capacities of custom in light of attempts to integrate them within state aspirations for environmental and social governance in Timor-Leste. By exploring the mobilization of tara bandu, we show how, within this historically contingent and fluid space, local communities pursue creative possibilities for bringing into conversation various and often juxtaposed, messy, and slippery dimensions of being and reality. This process includes an ontological dexterity that selectively brings things and matters together and, importantly, holds them apart. We identify some potential limits to this dexterity and the various exceptions and resistances that, for customary communities, are disabling rather than generative. For its part, the state and its bureaucratic apparatus is also struggling to reconcile its 'built-in' desire to improve, appropriate, and control governance processes (Li 2008), while at the same time seeking to benefit from the agentive power of these uniquely cultural approaches to nature.

The following case studies draw on research that McWilliam has carried out with Fataluku society over a period of two decades and that Palmer has carried out on tara bandu more generally in Timor-Leste between 2006 and 2018. The latter has included participant observation, carried out during tara bandu negotiations and related events, as well as formal and informal interviews with local community leaders, community members, Timorese civil society, consultants, academics, and NGO s. Relevant research has been concentrated in various localities of Timor-Leste, including Baucau, Lautem, and Viqueque in the east 
of the country and the municipalities of Ermera, Bobonaro, Liquica, and Ainaro in the west. Academic literature as well as NGO and media reports also inform the observations and analysis of tara bandu processes.

To provide a more specific ethnographic context for understanding the practical enactment of spirit ecologies, the following case study focuses on a concern with the realm of spirits, the agency of ancestors, and other entities and their mediation through modes of ritual action. These concerns are fundamental aspects of the customary governance of Fataluku-speaking communities of Lautem municipality (see Figure 1). Customary governance is defined here as an assemblage of cultural practices that are grounded in notions of spiritual blessing as well as sanction, and constitute diverse forms of moral obligations and gift exchange.

Fataluku spirit ecologies are complex cultural terrains with multiple interpretive dimensions. For most Fataluku, the experience of the 'spirit' domain is part of the lived reality of social life. People refer to this ever-present though largely invisible realm by the generic term tei-a concept that combines moral authority and protective familiarity with elements of dangerous uncertainty and retribution (akin to the Tetun notion of lulik). That which is tei is treated with caution, respect, and ritual restraint. The concept of tei extends to a wide range of polysemous forms, from spiritually charged locations across the landscape to certain forms of behaviour; the consumption of sacrificial meat (avoidance relationships); sanctioned names of origin ancestors; and group-specific knowledge of healing spells, sorcery, and ritual prayer. We agree with Pannell and O'Connor (2005:2) when they argue that 'the notion of tei is positioned in the centre of a discourse that explores the often perilous limits of sociality'; the idea of the sacred here expresses the inherent ambiguity of power in the indeterminate spaces between blessings and threats, malevolence and benevolence.

Within a broadly Catholic framework, Fataluku posit a continuum of classes of spirit agency, extending from clearly human to more-than-human forms, but the distinction in the end can be blurred as transformational processes are frequently a defining quality. This continuum also informs the idea of what has been referred to elsewhere as Fataluku 'inspirited landscapes' (McWilliam 2011) - a notion that speaks to ways of engaging pre-existing and emplaced 'spirit' forms with active processes of inspiriting as a means of legitimating residential presence and resource claims. This can include processes of clear- 


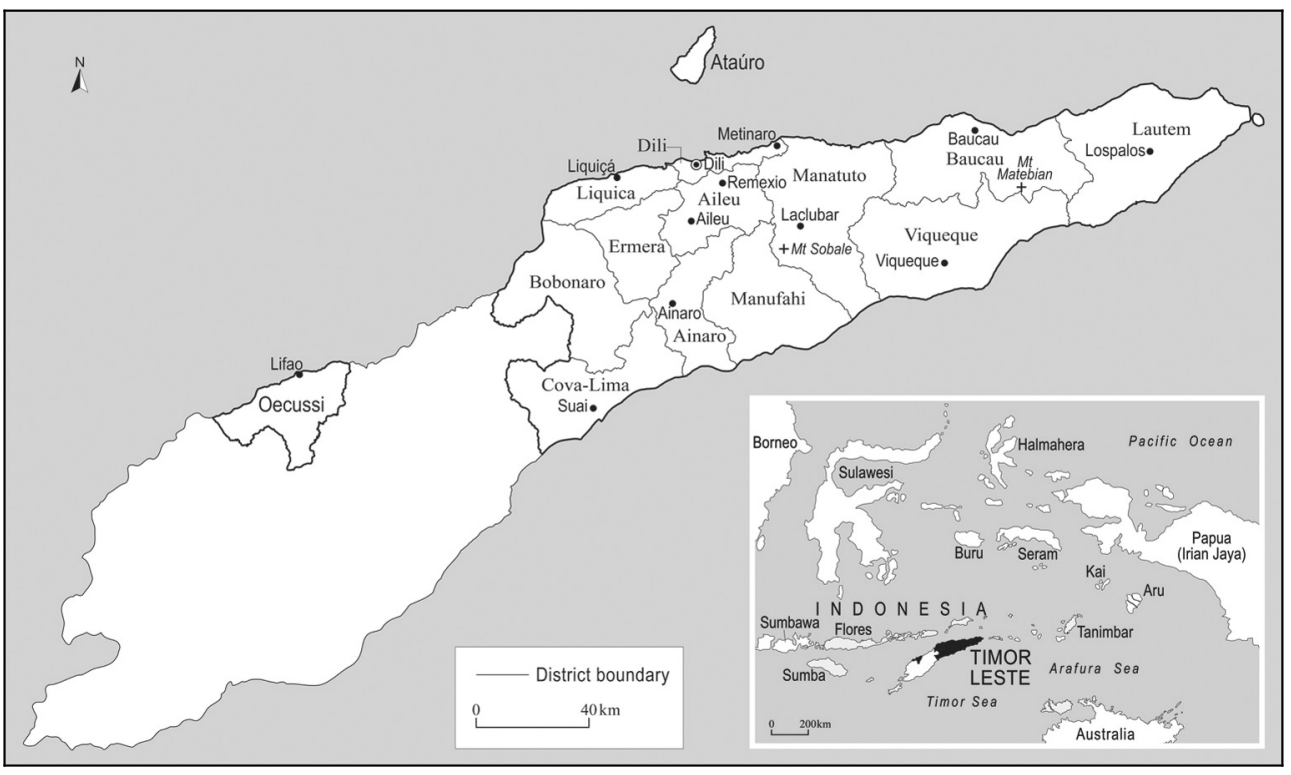

FIGURE 1 Timor-Leste municipal map COPYRIGHT: CHANDRA JAYASURIYA

ing and cultivating the soil, hunting and resource capture, and being born and dying in the land, all of which contribute to the conversion of the country over generations from the strange to the familiar, from 'other lands' to 'our' lands (see McWilliam 2011:69).

Fataluku cultural repertoires include wild spirit agents that can influence human actions in beneficial but also deleterious ways. These agencies comprise a very diverse range of powerful spirit owners of the land and waters known as mua ocawa (guardians of the land), often intimately linked to the origins of ancestral settlements. Other spirit entities include forms of land, forest- and water-dwelling spirits (ca-catu), as well as the bloodied and vengeful souls of those who have died a bad death (ula papan :: ula ucan $)^{2}$ and the elusive, shapeshifting witches (acar) who entice and consume the unwary.

It is said the wild tei of the land may be calmed or 'tamed' (tei ma'a varin pai) through the actions of human intervention. Sacrificial offerings of blood, offal, boiled rice, and palm liquor with appropriate invocations are designed to

2 Untimely death (for instance, suicide, falling from trees, accidental or intentional death) is inauspicious and results in the soul of the deceased (huma'ara) being abandoned and left to wander as a tortured and unconstrained spirit. 
address ruptures in relations and/or render them amenable to the service of the living land owners, while securing the protection of those residing on the land. But the nature of invisible, autochthonous spirits is capricious and demanding, as they can turn on their living custodians if relations are neglected or if they are addressed incorrectly. As ever, there is a high degree of indeterminacy and uncertainty surrounding ritual communication with tei forms.

The counterpart to these unpredictable spirit strangers is the immanent ancestral domain, and for Fataluku, ancestors matter in fundamental ways. All Fataluku are members of agnatic kin groups and trace their collective identity, mythic origins, resource attachments, and clan-specific knowledge through the memorialized settlement trajectories and actions of paternal ancestors. Collectively referred to as Calu ho Papu (lit: grandfather and great grandfather), the invisible presence and agency of ancestor spirits (i huma'ara) are conceived of as maintaining a kind of vigilant oversight of the social affairs of their living and visible progeny. Through prayer and sacrificial feeding (fané) ancestors are urged to provide blessings and protection for their descendants; to ward off illness and heal the sick; to bring abundant harvests and healthy babies; to restore reputations; and to alleviate suffering. For these reasons, life transitions and commemorations for newly deceased kin are accorded great importance and paid attention to by agnates and their affinal relatives alike.

For most Fataluku, ritual engagement with their house and clan ancestors is actively mediated through life cycle events of the household, such as baptisms, marriage negotiations and weddings, funerals and the consecration of graves, house inaugurations, opening new food gardens, and so on, all of which reaffirm the solidarity of shared origins and the expanded ancestral networks. At the household level the locus for ancestral communication is the sacred hearth (lafuru tei or aca-kaka). To celebrate life cycle events, kin gather to present sacrificial offerings to male ancestors, especially meat, comprising the thorax and internal organs of sacrificial animals (leura tei $:$ : ipilu tei). Ancestors are invited to assemble at the (sacred) hearth (aca-kaka na cuare) within the house and participate in commensality with their living male progeny. Engaging ancestors in this way evokes a symbolic conjoining of past and present and the celebration of origins as a source of continuing life and wellbeing.

Ultimately the Lautem landscape is a deeply enculturated one, littered with the signs and traces of group-specific sites of renown and generative ancestral power. Most people locate their origins in the long-range exploits of forebears who arrived along the coast of Lautem in their sea-going perahu (F. loi$a s u)$. Here they left mythologized inscriptions of their settlements in the landscape that are variously memorialized. They include carved sacrificial altars ( $i a$ mari tulia) that signpost places where ancestors made landfall; ancestral 'stone 
boats' (loiasu mataru) that lodged in the landscape and became 'fossilized' remnants of the original settlement; naturalistic figurines and carved posts (ete-uruha'a or sikua) located on hilltops, near springs and forested groves; and multiple stone-walled hill-top settlements (lata paru, pa'a makolo), often overgrown with dense vegetation and enclosing massive stone graves of ancestors and tei altars. Collectively, these sites identify the historical and material imprint of the ancestral presence in the land (McWilliam 2019). Each provides a focal point for ritual veneration by descendants, in the hope that blood sacrifice and prayer will resolve impediments to relations leading to the misfortune of afflicted members and/or bestow blessings of protection and abundance. These early and old places of ancestral presence are reputed to be the most powerful in terms of their restorative or influential affects. Their seniority, it is said, gives them the authority to assemble a wider group of more-than-human kin. But powerful ancestral sites are also fraught with risk, where errors in ritual performance and narrative address carry heavy sanctions, including illness and even death for practitioners. For those reasons, Fataluku generally rely on the knowledge and ritual skills of their leaders (laficaru, luku-lukun ocava) in this spiritual work. At other times, in the absence of a good reason, people tend to avoid approaching iconic ancestral sites or do so with much caution and care, especially those belonging to others.

The central point of this excursion into Fataluku spiritual ecologies of place is to highlight the powerful, thoroughgoing but often indeterminate nature of the properties attributed to place and its implications for customary governance. Ritual invocation and commensality in these spirit ecologies have been an important part of the post-conflict rebuilding process for Fataluku communities. They reveal a 'meshwork' of shared concern around giving thanks to ancestors for their protective role during the years of struggle; address points of resistance, breaks, or blockages in relations and apologies for inadvertent neglect of their needs; and work to cleanse the collective group of the lingering effects of wrongdoing, while seeking guidance, blessing, and support for a better future.

In the crowded landscapes of Fataluku spirit ecologies it is evident that individuals, householders, and extended family groups are by no means passive recipients, beneficiaries, or simply victims of ancestral and other spirit actions. Rather, the spiritual domain is a highly interactive field, one amenable to manipulation and processes of discovery, interpretation, and resolution for 
many everyday afflictions and suffering that affect households and the networks of more-than-human kinship and alliance in which all are enmeshed. Key to this complex is the widespread use of diagnostic techniques of divination performed by ritual practitioners (i navarana) skilled in specific mantras and interpretive knowledge. A range of techniques is employed, often accompanied by the sacrifice of domestic animals (especially chickens and pigs) and the close inspection of the pancreas (ari moko haca) and liver (ari haca) for blemishes, shadows, and signs that portend unresolved concerns and threats (see McWilliam 2008). One common divinatory technique, known as mu'ufuka totole, involves the use of a soft inner banana stem, a small knife, and the practice of asking a sequence of questions of the ancestral domain, slicing small segments of the stem for each enquiry and watching how they land. The result determines whether the question is answered in the positive or negative. These interrogative procedures may take some time before the specific source of affliction or ill-fortune is identified. Typically they are located in behavioural acts of commission or omission on the part of the patient/supplicant, which are affecting their relations with the more-than-human ancestors or nature spirits. Subsequently a variety of performative actions and ritual remediation is usually prescribed. The practice of mu'u-fuka totole is a widely used tool in Fataluku society for divining cause and effect as well as confirming the efficacy of actions through subsequent sacrificial offerings. In Figure 2 the practitioner is using this technique to assist a small group of male siblings (noko-kaka) to resolve the cause and problems associated with a miscarriage of the wife of one of the participating brothers. Unless ritually contained and its effects neutralized, the spirit agent (moco-i-can: lit: 'the fallen child') can be a cause of expanding misfortune and accidental death (characteristically, from falling). The ritual also brings together the symbolic elements of the spirit child (blood, bones, and burial cloth) that will later be bundled and buried in the ancestral settlement of the father, thus containing and integrating the dangerous spirit into the ancestral collective.

The use of divinatory techniques, such as mu'u-fuka totole, alongside sacrificial offerings and the various prescriptive actions that supplicants are obliged to follow are important cultural mechanisms for addressing illness, disruptions, and uncertainties in social life. In other words, the affects revealed in physical bodies are often related to transgressions against the body social and the complex web of mutual indebtedness, obligation, and exchange that shapes and informs the broader governance of social life (McWilliam 2008).

Aside from investigating cause and effect of human actions via ancestral direction, Fataluku also draw upon specialized cultural knowledge to protect and conserve household or group possessions and resources through the applica- 


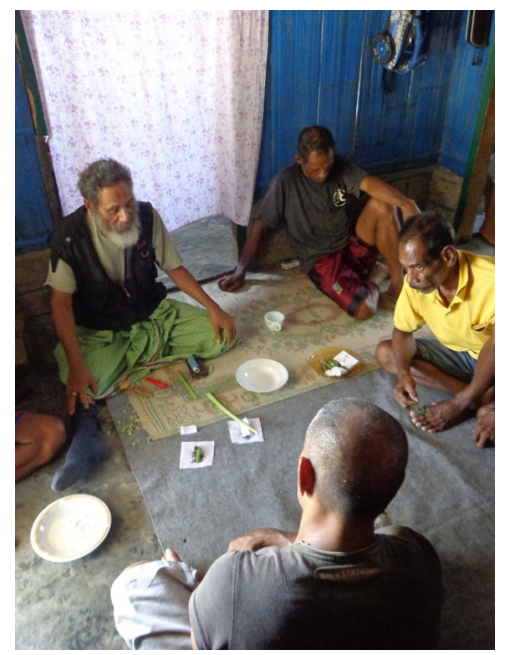

FIGURE 2

Fataluku divination ritual

PHOTO: ANDREW MCWILLIAM

tion of potentized prohibitions and sanctioned measures. The generic Fataluku term for these protective invocations is lupure, a local variant of the wider Timorese (Tetun language) concept of tara bandu, which is further elaborated on in the next section. The Fataluku practice involves the placement or fixing of a sign or marker, often botanical in form, together with appropriate words to charge or activate the protective device. Each ancestral origin group has its own forms of lupure and ritual invocations. The intent of lupure is to draw upon the powerful possibilities of the ancestral/spirit realm and enable release of its punitive actions against transgressors. The use of these restrictions is often applied to food crops and commodities such as coconuts, areca, and other tree crops (vata lupure). Here the prohibition is signalled with a material marker made from palm leaf affixed to a wooden post (lupure pacun), but lupure pacun can also extend to restricting access to ripening crops such as maize (cele) or wet rice fields (ale ira). Prohibitions may be applied individually or extended as general restrictions on harvesting; sanctions for transgressing these prohibitions are generally non-specific, but there is a widespread view that a key consequence of theft from items placed under lupure prohibition is the affliction of genital shrinking or genital retraction in the perpetrator leading to death if untreated. Fataluku allude to this effect with the term molu molunu, meaning to 'disappear'? In due course the harvest prohibition

3 The notion of genital shrinking is widespread across Southeast and East Asia. In the literature it is often associated with the Makassar or Bugis term koro (meaning wrinkled or shrunk). Edwards defines this as a psychogenic syndrome of the subjective experience of 
will be lifted or rescinded (mamihe) by its owners and, with it, any existential threat to personal or material injury.

The different ways of proactively engaging the agency of Fataluku spirit ecologies, as highlighted above, illustrate forms of customary governance at different levels of social inclusion, moral injunction, and behavioural effect. They are distinctly local in flavour and highly instructive in offering specific cultural expressions of what are widely shared practices enacted across the ethno-linguistic landscape of Timor-Leste, where twenty or so distinct language communities share a common Austronesian heritage. People find continuing solidarity, comfort, and efficacy in the authority of ancestrally constituted social and environmental governance practices tied to behavioural expectation.

In developing the concept of intergenerational wellbeing from its base in an ever-transforming customary realm, we would compare this with other, more traditional and positivist notions of wellbeing expressed in governmental health, security, and environment sectors. As such, we also need to ask how these ideas and practices might be integrated successfully within secular state policies and government programmes of service delivery that, to date, have largely ignored customary practices and orientations. We recognize the need to move beyond an acknowledgement of pluralist approaches towards pathways for active engagement. This requires careful research and more innovative analytical frameworks that can overcome the possibility of formalized governance interactions being little more than a means of demarcating and controlling the customary economy (Zerner 1994:1107; 2003).

Exemplifying this challenge in Timor-Leste are the multiple, locally enacted customary practices of ritualized prohibitions, widely glossed as tara bandu in the official language of Tetun. Tara bandu practices are often referred to as 'seasonal or periodic resource-harvesting restrictions' (Meitzner Yoder 2005:249), but, as noted above, they can also be more broadly interpreted as a practice that regulates diverse place-based social and environmental relationships. They are, in other words, forms of sanctioned behaviour directed towards environmental or social organizational ends (Belun and the Asia Foundation 2013).

penile shrinkage accompanied by extreme anxiety, and postulates that 'genital insecurity may be a basic feature of Indonesian-Malay psychic and cultural life' (1970:168). See also Mitchell 2003 . 
Like the Fataluku notion of lupure pacun, these ritual prohibitions are generally invoked to proscribe behaviours considered damaging to social cohesion and/or the integrity of the local environment. Elevated as a tool for forest protection by the Portuguese at the turn of the twentieth century, over several decades the practice of tara bandu became the favoured 'indigenist ideology' supported by the state (McWilliam, Palmer and Shepherd 2014). This officially favoured status, which afforded it recognition as an 'indigenous environmental protection practice', has been reinvigorated in the independence era with similar intent. Alongside community and non-governmental organization levels significantly embracing the process (McWilliam, Palmer and Shepherd 2014), tara bandu has developed as a 'traditional' mechanism that has garnered significant attention and traction in the development of formal resource-management laws, many of which are being drafted by 'expert' foreign advisors and well-intentioned policy makers (Jackson and Palmer 2012). Furthermore, since 2013 the Secretaria de Estado do Meio Ambiente (Secretariat of State for the Environment) has also supported these ritual injunctions through small allocations of funding and, in some cases, the attendance of senior government members. Tara bandu, it seems, is now valued by the state as a local mechanism 'to conserve and promote the environment and the preservation and sustainable use of natural resources. ${ }^{4}$

But what is understood today as the bandu process is usually conducted at the sub-village, village, or inter-village level, at locally specified intervals (ranging from months to years). While the ceremony may be announced and co-ordinated by the local political leader (usually the village head), the lawmaking power emanates from the ancestral and ritual authority of the ancestral house or houses of one or more of the area's senior origin groups. Ceremonies typically involve invitations to people from beyond the village to witness the ceremony. Invited guests can include political and ritual leaders from neighbouring communities, members of the clergy, and representatives of the local government, police, and civil society. The ceremony itself may be a multi-day event. The months of preparation include special ritual speeches; celebratory ritual dancing, drumming, and singing; betel nut exchange; animal sacrifice (the type of animals, their colour, and required number depend on the traditions, local capacity, and the subject of the bandu itself); divinatory techniques including an augury based on these animal's internal organs; and communal feasting. Prior to the public feasting, the main ritual elders must also come

4 Article 10(2) of the Draft Water Resources Law, Ministry of Infrastructure, Dili, Timor-Leste, viewed 10-2-2012. 
together in the commensality of specially prepared sacrificial foods, which are shared with the ancestral spirits of relevant 'houses', lands, and waters (spirits which may also be consubstantiated in animal form; see Palmer 2015). In most areas, following the ceremony, large ritual 'mother' posts and smaller 'child' posts will be placed around the prohibition area and relevant symbols of the prohibitions (bandu) hung (tara) on them. They commonly include skulls of the sacrificed animals, forest foliage, crop items, and (depending on the locality of the pole) receptacles of water and hand-woven symbols of wild animals.

Another purpose of the tara bandu is to honour the ancestral sites that connect the lands of different houses, sub-villages, and villages to a particular ritual domain. In these areas the 'child', or subsidiary, posts are erected and accompanied by prayers. The practice reinscribes the traditional order of ancestral relationships that speak to the origins and political configuration of the local community. It is also associated with a suite of practices in the ritual domain that seek to assure and generate agricultural prosperity as well as intergenerational wellbeing through carefully attuned and calibrated communication with founding ancestors and the autochthonous and newcomer groups who now inhabit the area.

Yet, in what may be read as both a strategic intervention and a reminder of the significance of custom, the placement of these posts has been known to feed simmering independence-era disputes over land and village administrative boundaries, particularly in Timor's urban and peri-urban areas. These tensions emerge as a result of particular instances of tara bandu, but the disputes are, at their sources, a legacy of colonial- and Indonesian-era administrative processes that have, to varying extents, embraced, subverted, or ignored local 'custom' (Fitzpatrick, McWilliam and Barnes 2012; Shepherd and Palmer 2015). They are also a consequence of the emerging 'development' value attached to these lands. In many areas of Timor-Leste, development initiatives have fuelled mistrust and suspicion between sub-villages and villages, especially when 'newcomers' renege on their commitments to recognize and reaffirm the founding rights of particular land custodians to ritually oversee the use of land and resources (Palmer and McWilliam 2018). In these contested circumstances, independence-era attempts to secure resource regulation and village boundaries through either customary or formal, state-based agreements can work to undermine solidarity and foster socio-political fragility and conflict. Nonetheless, in contrast to the prospects for effective customary governance in much of neighbouring Indonesia, across rural Timor-Leste a high proportion of environmental and social disputes, including serious divisions, is still 'conducted between parties who are inclined to obey the same local rules of conduct and the same traditional authorities' (Henley and Davidson 2008:848). 
To what extent this might change in the future is a moot point (Palmer and McWilliam 2018).

\section{6}

\section{Promoting Tara Bandu}

These days as new resource development policies and regulations are rolled out across Timor-Leste, they are also engaging with and are co-constituted by, the renewed desire among populations to re-instigate a range of house and community governance rituals. These rituals mark out connections across space and time and define the limits of authority in particular jurisdictions. They are, therefore, significant as the self-conscious expansion of the meshwork of local political and ritual spheres into the national body politic.

In these scaled-up and often state-sanctioned tara bandu-like events, distinctions between ritual/spiritual and political power are relationally defined vis-à-vis others in the community and vis-à-vis the state. In these recursive political and ritual spheres of governance, those most closely associated with ritual/spiritual power are realized only in context and in diarchic or complementary terms. Across the country, house-based communities draw on these dual categories to represent a range of collaborations between such complementary powers, all of which are recursively replicated at multiple levels (see Palmer and McWilliam 2018). In diverse and often new ways, tara bandu practices combine these diarchic political and ritual/spiritual governance functions, mobilizing ancestral powers to punish both socio-ecological and ritual transgressions.

In these circumstances, we argue that local communities are seeking an active role in the designation and management of their lands and waters as well as space for performing resource management capacities through practices such as tara bandu (Palmer and Carvalho 2008). To this extent these performances are also important political interventions into land resource governance. But they do not always work out in practice. Some tara bandu events are discussed and even planned by communities but never implemented (ostensibly for funding reasons; see below); others happen but have little desired effect (also often for funding reasons; see below).

From a local standpoint, tara bandu is not simply about conserving and promoting, as the Timorese state characterizes it (the practice is defined in terms of 'the environment and the preservation and sustainable use of natural resources'). Rather, it is more broadly interpreted as, regulating a range of social relationships, land and resource rights as well as moral action. In this sense there is no separation between a community's natural, cultural, and 
economic resources. Based on experiences elsewhere in the world, and evident historically in Timor, activating these kinds of rituals as 'counter maps' for social and environmental governance risks political co-option or even repressive legal sanction. Yet this is a risk that local peoples have so far been willing to assume, realizing perhaps better than most that, negotiating the 'friction' (Tsing 2005) of these meshworks of material imagination and practice is always messy, incomplete, dynamic, and opportunistic.

For its part, the recent responses of the Timor-Leste government have been to adopt a supportive stance towards the enactment of public tara bandu. This positioning in part reflects their own lack of capacity to ensure effective environmental monitoring and protection. As noted above, government support in this regard has included the provision of state funds to promote the ritual enactment and observation of the prohibitions. From a government perspective the funding is intended to ensure effective support for state regulatory proscriptions against undesirable practices, such as logging and clearing forests, burning grasslands, hunting game, livestock theft, and so on. In these collaborations, customary authorities are, in a sense, very much co-opted by way of government support funding to implement restrictive forms of behaviour on pain of sanctions, usually including fines and spiritually based (lulik) punishments in the form of illness or misfortune to perpetrators. In other words, we can see the state demonstrating a willingness to draw on the spirit ecologies of local Timorese cultural constructions of ritual and behavioural transgression to facilitate its own environmental agendas.

To be sure, in some areas and at certain times the process of collaboration between state and customary authorities over natural-resource management has been characterized as working largely to the benefit of local peoples and the nation state (see Meitzner Yoder 2005). Elsewhere, however, particularly around the nation's capital, there has been a problem with the selective use of the process by government authorities (Meitzner Yoder 2005:252). In these cases the government has become involved with tara bandu ceremonies and provided money and animals for the rituals, but has generally not followed through with the process beyond the theatrical staging of a ceremony. Consequently, local people have tended not to take the process too seriously, and prohibitions have been breached or set aside shortly after their ritual enactment. ${ }^{5}$ In other cases, collaborations have focused selectively on particular environmental elements of the tara bandu process, but this failure to engage with the full spectrum of the usual social and environmental prohibitions has

5 Personal communication with D. Carvalho, Director, Haburas Foundation, Dili, April 2008. 
weakened the bandu implementation and no doubt the regard in which the customary institution is held.

Our forestry colleague, Snr Fernando Santana, has observed in this respect that too often these days the institution of tara bandu has become ineffective, operating as gestural politics and symbolic performances designed to appease government expectations and the funding that accompanies such ritual performances, but without the weight of sanction, spiritual or material, that encourages compliance. 'More tara than bandu', is how Fernando expressed it, meaning a greater focus on ritual performance than invoking the prohibition, where people break the established rules with apparent impunity. Partly he thinks this is due to the unwillingness of local authorities to enforce sanctions, but he also considers that customary leaders were often reluctant to 'activate' the spiritual (lulik) power of the prohibition out of a concern for the wellbeing of their neighbours, who may actually be harmed or die as a result of wilful transgression of the ban. This is especially the case when the ban relates to matters of more interest to the state than local communities (for example, a blanket ban on hunting wild animals or land clearing). The issue highlights the inherent risks of applying traditional practices constituted in local domains as a vehicle to further the environmental policies of the state, often to the local people's detriment, and in places where government funding may well undermine or disenchant the moral injunctions attached to ritual invocation itself. It also highlights a community strategy to ameliorate this risk, namely watering down, refraining from, or holding apart the process from particularly powerful ritual invocations.

As noted above, in most cases there is a surface-level pluralist accommodation between Timorese Catholic and ancestral traditions, but in some areas, open hostility towards 'traditional' practices by representatives of the local Catholic Church works to undermine the operation and implementation of community-based rituals such as tara bandu. Among more puritanical Catholic and newer Protestant traditions, apparently on the rise in the nation's capital (the seat of the government and the bureaucracy), people often express outright objection to engagement with customary practices (Wiyono 2001). In the process, they reprise the historical disdain of the modernizing urban centres (sidade) towards the perceived fetishized and backward people of the hinterland and hills $(f o h o)$, seeking instead a break from ancestral religion and associated practices. On the surface this break entails both a rejection of responsibilities towards enmeshed customary social relations as well as beliefs in ancestral sanction, in favour of a radical reshaping and codification of an increasingly individualized habitus (Strathern and Stewart 2002; Schram 2007; Keane 2007). Yet, at the same time, these more institutionalized approaches are fashioned as 
a radical change from ancestral traditions of 'stone worship and animal sacrifice'; ironically underpinned by a firm belief in the need to continually exorcise the fearsome and ecologically diverse spirit beings from unwell human bodies (Palmer, Barnes and Kakuma 2017). Hence, despite the potential blockages, resistances, and friction in the meshwork of customary practices created by newer forms of Christianity, the continuing efficacy of affective Timorese spirit ecologies persists as an existential reality.

The lessons we draw from this experience of pulling together or distancing customary and other sets of practices are that sanctioned custom designed to prohibit or deny certain behaviours retains its efficacy, its conforming authority, only when the consequences for human wellbeing of transgression are realized and serious (whether or not these are framed as customary or Christian spirit ecologies). This is not to say that state-supported symbolic action cannot be effective in changing behaviours, but its secular authority to motivate compliance is necessarily of a different order. Below we will argue that the urge to 'scale up' customary governance in an undifferentiated way and to secularize such processes alongside more formal administrative structures is, in fact, part of the problem.

In the municipality of Baucau, locally enacted customary practices of ritualized prohibitions are known as lubhu badu6 in Makasae and lubhu badu (literally, 'the prohibition post') in Waima'a. These tara bandu-like events, once at the heart of the relationship between local ritual communities, are said to be derived from more localized traditions of lubhu sari (Makasae) and lubhu gege (Waima'a); the same concept known in Tetum as horok and in Fataluku as lupure. These latter processes refer to localized, hamlet-level rituals in which spiritually infused objects (T: ai-moruk, medicine or 'bitter wood') are hung in public view to activate lulik prohibitions of the highest order. By contrast, when 'scaled up' to the village or sub-municipality level, modern-day performances of tara bandu events (such as lubhu badu) do not usually involve the placement of spiritually infused objects on the bandu post. While sanctions in these village-level tara bandu events are still activated by ancestral prayer and offerings, the even more dangerous properties of ai-moruk used in lubhu sari or lubhu gege are usually omitted. Nonetheless, in these cases where the aim of the scaled-up rituals is also to invoke, reinscribe, and honour ancestral placemaking practices (and the boundaries of their authority), the use of revered ancestral prayers and the sacrifice of particular animals may have similarly potent and behaviour-controlling effects as the use of spiritually infused $a i$ -

6 Also known as lubhu etena (see da Costa, da Costa Guterres, and Lopes 2006:94). 
moruk. In such cases, there is as much at stake in the contents of the tara ('that which is hung') as there is in the bandu ('that which is prohibited/regulated') itself. Yet, as noted above, in cases where these ancestral place-making acts are now overlaid with colonial-era administrative structures, the invocations may struggle to achieve complete authority and, in some cases, cause resentment and dispute. Sometimes such issues need to be referred to a higher-level administrative authority for resolution, usually the sub-municipality. It is also worth noting here that the administrative role of the sub-municipality (posto) lies outside the conventional purview of 'traditional' governance structures. When this level of administration is called upon to arbitrate everyday affairs, the dispute is effectively seen as lying beyond the (ordinary) authority or capacity of the customary realm. In most cases, rural people prefer to avoid such an outcome.

Thus, while customary resource-management practices have undergone a local resurgence in post-independence Timor-Leste, a host of post-conflict and post-colonial issues constrain full recovery. These issues usually involve, firstly, the challenge of collaboration among diverse stakeholders while pointing to the legacy of colonial and post-colonial abuses and disruptive administrative changes; and, secondly, the failure of mainstream resource managers to integrate resource management into the realm of social and political relationships, preferring instead to limit its scope to regulatory and environmental relationships. Selective engagement with ritual activities is also likely to be unsuccessful. From the perspective of local communities there may be a lessening of belief or faith in spiritual sanctions and, conversely, a heightened concern about the dangers involved in enacting forms of sanction that are unlikely to be upheld.

A further, related issue affecting some areas in Timor-Leste is the loss of knowledgeable ritual leaders to carry out traditional resource management practices. Some of these people may have died during, or subsequent to, the Indonesian occupation; others may have been sympathizers with the Indonesians and fled across the border into West Timor in the turmoil following the referendum (Damaledo 2018). Due in no small part to the societal disruptions of the Indonesian occupation, the death or departure of these customary leaders has created a politico-ritual vacuum at the local level. In Indonesian times, when such rituals were authorized and their practice permitted, Indonesianappointed authorities (such as the village head) are said to have often chosen inappropriate people to lead the rituals. This resulted in both a desacralization of the process and the implementation of ineffective, if not potentially dangerous, ritual practices. Today, community members are usually reluctant to carry out rituals where the necessary expertise is felt to be lacking. 
In Timor-Leste a number of researchers have been critical of locally idealized representations of tara bandu and the tendency to encourage 'invented practices of tradition' (Meitzner Yoder 2005:252; Shepherd 2013). Yet, by adapting Ingold's concept of the meshwork and extending it to include processes of resistance and the need to address blockages or ruptures in the flow of life, we argue that it is more useful to think of these changing conditions and their advocates as being engaged in an ambiguously shifting array of 'representational economies' and 'different modes of objectification' (Keane 2007:269). They speak and respond to the demands of a meshwork comprising spirit ecologies; intergenerational wellbeing and associated indigenous practices; intra- and inter-community politics; regional, national, and international conservations; and development agendas. Such conversations and collaborations through the meshwork are simultaneously situated, dynamic, and opportunistic, even as the outcomes in many ways will always be either unsuccessful, unknown, or uncertain.

We have thus far argued that the power of tara bandu is established through its links to a moral economy based at an ancestral clan- or house-level relationship rather than more abstracted, 'scaled up' articulations. In the fractious postconflict environment of Timor-Leste, it is widely believed that the attributes of a community-based, ritually sanctioned prohibition will result in higher levels of compliance with the prohibitions - higher than would be expected with the simple imposition of government laws and regulations. At present, approaching two decades since independence and at the beginnings of the revival of tara bandu practices across Timor-Leste, the state is now indicating that it may move towards the formal legislative recognition of tara bandu as a customary resource-management practice. But given the dangers of co-option, the continuing absence of formal legislative recognition may well be considered by some to provide a more desirable and indeterminate state of affairs-one that enables local expressions of tara bandu to flourish and expand without unnecessary, heavy-handed regulation. The issue divides opinion especially among local people themselves, who are keen to see state recognition of their customary laws (Carvalho et al. 2008). Many community leaders across Timor-Leste also express a desire for the government to authorize and support practices such as tara bandu, with some advocating that these legislative forms will give effective constitutional recognition to traditional laws and customs.

Already there are a number of civil society groups who are actively supporting the documentation of community-specific tara bandu processes in the hope of pushing forward with governmental recognition. In other cases, sim- 
ilar initiatives have stemmed from within the community itself, encouraged by the presence of educated individuals familiar with the formal recognition and codification of customary law in other jurisdictions. ${ }^{7}$ But questions of how this recognition might be activated and whether or not such laws should be formally codified need careful consideration.

In the early years of independence, in the enclave of Oecusse, for example, active collaboration between customary and government forestry officials was underpinned in each instance by the creation of formal 'letters' documenting a combination of traditional practices and state forestry laws, which constitute that particular tara bandu (Meitzner Yoder 2005, 2007a, 2007b). But to date it remains unclear from the tara bandu documents that are emerging through this process whether these written regulations are intended to be guidelines for practice by the relevant community or imposed regulations to be applied and adhered to indefinitely, regardless of constantly changing contexts and circumstances. 8

On the one hand, communities 'hosting' government-endorsed and increasingly standardized tara bandu events have begun to question the source and necessity of such restrictive, or 'non-negotiable', actions. Critics suggest that this accommodation is rapidly becoming a new form of imposition on existing local customary practices. Still others, who acknowledge these tensions, make hopeful comparisons between formal institutions of social and environmental governance and the protocols of tara bandu, referring to the coming together of soft-state governance approaches and the absence of lulik sanctions-which nonetheless may have some beneficial effects at lessening otherwise indiscriminate forms of post-conflict resource-harvesting. Similarly, this anticipated coming together of benefits is also sometimes extended to state aspirations for localized economic development. For example, in a number of tara bandu processes associated with coffee-growing districts in the mountainous west of the country, restrictions on the number of animals that can be exchanged and sacrificed between houses during life cycle events are often added to the list of 'environmental' bans (Palmer 2007; Silva 2016). While such tara bandu processes were initially embraced at the community level as a way to tackle

7 Personal communication with D. Carvalho, Director, Haburas Foundation, Dili, April 2008.

8 Meitzner Yoder (2007b:48) writes that the formal documents known as 'letters', which are produced as an outcome of the customary-state collaborations in Oecusse, have over time become increasingly detailed and elaborate in terms of identifying the objects of prohibition and the fines associated with particular breaches. She notes, however, that in most cases following a breach, protracted community negotiations were still the norm to settle on a specific fine, 'indicating that the quantities outlined in [stipulated] fines often serve [simply] a symbolic function' (Meitzner Yoder 2007b:49). 
perceived excesses in localized post-conflict land-clearing and ritual exchange, it has been argued that over the years many of these processes have morphed into a more insipid type of state-sanctioned 'environmentality' (Cullen 2016). People now question the propriety of bans enabled under the guise of customary governance. As one young man in the municipality of Ainaro remarked in relation to regulations on life cycle exchanges: 'It makes us sad, ashamed and angry. We increasingly have to hide out in the coffee forests to carry out ritual sacrifices that exceed those allowed under the tara bandu law. If we get caught, we risk being locked up and fined. ${ }^{9}$

On the other hand, as described in the brief case-study below, for other participating communities, post-independence tara bandu events and governance arrangements have been and remain a source of great community pride. There they are viewed as a tangible expression of a community's commitment and attentiveness to intergenerational wellbeing and are valued as an explicit demonstration of the faith and efficacy of customary modes of governance. From this perspective, whether or not these tara bandu rituals and associated 'modernist' paraphernalia (written documentation, formal signing ceremonies, stipulated fines) are initiated from within the community or beyond is not relevant to the greater project of the pursuit of intergenerational wellbeing. Of more relevance is that the protective agency of the ancestors, the animals, lands, and waters is being enabled and even brought into dialogue with the state, even if the latter is interested primarily in the deployment of prefigured environmental or 'economic pedagogies' (Silva 2016).

In the example below, we reflect on a post-independence tara bandu in the Baucau municipality in the east of Timor-Leste. In the rural inland community of Bercoli, which comprises one ancestral domain but two administrative villages, the most recent tara bandu came into force in 2016. This event followed the participation of a number of senior elders in a workshop of customary leaders from across the country. The workshop was convened by an international NGO to discuss ways in which they could best enable and support localized tara bandu initiatives. Returning from this workshop, the men worked with the Bercoli community on a nine-month socialization process to negotiate the terms of the tara bandu..$^{10}$

With the financial and material assistance of the NGO, a formal 28-page document was produced to outline the specific laws that would be put in place. A community-wide tara bandu ceremony to 'open' (activate) the prohibitions

9 Personal communication with community member, Ainaro, September 2018.

10 Their first official post-independence tara bandu was carried out in 2008. 
was conducted in October 2016. In the written document, the community negotiated and set prohibitions that comprised; (i) specific activities relating to non-serious criminal matters of violence against persons and property as well as theft; (ii) disputes over land, land use, and property (for example, related to the cultivation of fields, water-sharing, crop destruction by livestock, and unauthorized harvesting of forest products); (iii) destruction of public property; and (iv) matters of divorce, adultery, and family disputes. Basic principles were also outlined covering the conduct of mediation processes, the financial costs of each negotiation stage, and the relevant fines.

A village committee was established to oversee and implement the tara bandu, which would stand for the next seven years. The committee comprised the senior customary ritual leader or lia-na'in (custodian of the words), who had attended the initial, national-level tara bandu workshop, and other senior ritual and political leaders at the village and sub-village levels, as well as representatives of youth and women's groups and the local Catholic Church. Those who did not comply with the processes set out for the meditation of such cases would have their cases referred on to the police and formal justice system.

At the time of Palmer's first fieldwork in the community, in January 2017, the tara bandu was anecdotally hailed by many local people as a successful initiative that had strengthened the communities' cohesion and commitment to customary regulatory and dispute resolution processes. Those tasked with mediating disputes were regularly being called upon to do so at the sub-village level, leading to many customary interventions to resolve disputes over access to land (especially fields) and inter-family relations (especially divorce). This was an important intervention, as the period of conflict and civil disruption under Indonesian occupation had displaced many households and disrupted collective customary governance.

Soon after the tara bandu was initiated, it was reported that the process had already begun to address these issues of social cohesion. At the inter-village level, two corrosive disputes were mediated successfully including one arising from a violent incident at a 'friendly' inter-village football match. The skulls of a buffalo and goat signalling the animals sacrificed to resolve the dispute were displayed prominently outside the administrative office of one of the villages. The ability to address entrenched and periodic social conflicts was continually referred to as a major outcome of the renewed tara bandu process.

In mid 2018 Palmer returned to the community for a number of months. There she lived in the same household as the senior lia-na'in, who is also the president of the tara bandu committee. Every few days, she observed and/or participated in conversations between those involved in various conflicts (and/or their emissaries) and the senior lia-na'in. By the time the con- 
flict required his counsel, it had become a seemingly intractable problem, one eluding resolution at either the kin group or sub-village level. The possibility of the issue escalating further and involving state institutions was by then also a matter of consideration and concern. Yet, in all instances observed during this period (most of which involved disputes over land), the looming threat of outside involvement also worked to bring the parties together to find a solution. People were keenly aware that state courts created winners and losers, and most people preferred to find ways of living together harmoniously.

Other frequent callers to the house during this period were those involved in the reconstruction of origin houses (uma lulik). While this is not a part of the tara bandu process per se, it is intimately connected to the functions of localized customary governance. House reconstructions involve negotiating past, present, and future relationships among members of the village community as well as inter-married (affinal) and more-than-human kin of house communities from elsewhere. While these negotiations focus on matters of alliance and ensuring intergenerational wellbeing, like a tara bandu process they also involve honouring ancestors, local histories, and the need to painstakingly negotiate dynamic house and associated interpersonal relationships. Indeed, the commitment to honour relations between origin houses is arguably the true basis for a functioning tara bandu.

Before leaving the village, Palmer asked the lia-na'in if she could access formal village-level documentation relating to completed tara bandu mediation processes. She sought a documented 'account' of the range of issues and conflicts that had arisen during the last two years. He had previously told her that such a 'book' was in the making and that the malae (outsiders) who had helped instigate the tara bandu would be coming back soon to collect it. Yet, by the time she took her leave, the malae had not arrived.

When asking a second time about the possibilities of obtaining such documentation, the lia-na'in replied to her in frustration: 'You already have the "book". All the details are there. That's all you need.' Apparently the lia-na'in was referring to the 28-page tara bandu document. Clearly for him this 'founding' document, which he himself could not easily read, was enough to make the process legible - even though, as his comment suggested, the process of mediation was not at all readily evident. Along with the fact that many of the village's customary leaders are also illiterate, it is debatable what actually might constitute a successful or completed tara bandu negotiation. When is such an issue resolved or even distinguishable from other related and likely ongoing negotiations? The fact is that local commitments to tara bandu in this sense refer not to a clearly defined set of processes but to a whole lifeworld (or mesh- 
work) of interrelationships that remain, for the most part, opaque to outsiders. But clearly and for a variety of reasons, village authorities aspire to make their worlds legible and 'accountable' to the people and organizations whose help and resources they need.

Customary communities in Timor-Leste are thus well aware that they are engaged in an experiment 'across worlds', one that strives to shape 'how things could be' by drawing together, and at times holding apart, the often divergent and conflicting logics that shape and cultivate new possibilities for the future (Salmond 2014:304; Palmer and Carvalho 2008). While communities have, on the whole, engaged enthusiastically with the state and others to implement new tara bandu processes, we have seen above that the diverse contexts in which these processes have been enacted has required a constant assessment by these communities of the effects on more-than-human intergenerational wellbeing. This reflexivity, and the associated need to continually renegotiate ritual-political structures and processes in new governance contexts, is neither surprising nor novel for Timor's diverse customary communities (Palmer 2015:174). Nonetheless, rapidly changing post-independence circumstances, aspirations for land and economic development, new resource laws and policies, and the demands for transparent outcomes will no doubt increasingly challenge the possibilities of such collaborations. At present, beyond irregular, one-off support for particular tara bandu events there is little direct funding or material assistance provided by the government or NGOs for local people to manage their ancestral commons. As a result, tara bandu processes, which engage government and non-government agencies, remain a (less than ideal) option that local people may choose to 'opt into', and which they must continually negotiate.

\section{Conclusion}

In this article, we have sought to illustrate how 'scaled-up' customary mechanisms, designed to manage local and regional resources across Timor-Leste, struggle to gain traction in the post-independence environment. While there is a broad spectrum of potential relationships, expected behaviours, and obligations operating within local spirit ecologies, only some are being mobilized to express what is glossed as customary practices of tara bandu. Issues of local governance are critical to tara bandu implementation and impact, but so, too, is the extent and style of engagement by other environmental-governance actors across Timor-Leste. The remarkably widespread level of community support for tara bandu and its associated diverse practices currently lacks 
what is required for any regulated and successfully expanded implementation, whether at the village, sub-municipality, or national levels. What is usually missing is an engaged respect by those in power for the context-specific, spiritually sanctioned, dynamic traditions and behavioural expectations that underpin local tara bandu institutions. As our examples in this article illustrate, the need for these kinds of sui generis governance rituals to emanate from, and remain under the full control of, recognized local, ritual, and political specialists is a primary, but much overlooked, principle of customary authority (and efficacy) across the country.

A further matter for consideration is that even though communities will generally agree that tara bandu in its diverse cultural expressions is a key mechanism for halting the indiscriminate felling of timber, burning of grasslands, and hunting of animals, the state, by contrast, seeks to impose a generalized ban on these activities. Thus, while both assert the need for tara bandulike events to ensure community compliance, competing objectives undermine the very possibility of collaboration or of achieving environmental conservation via an actively engaged local population. This issue arises because of the inherent contradictions of purpose. For customary communities, the priority is to maintain respectful relations and exchange relationships with one another and the local spirit ecologies that inform and enliven social life. Under state conservation approaches, the central importance of the morethan-human kin networks are considered irrational and rendered illegitimate (Gombay 2014; Blaser 2016). The government, for its part, with good intentions seeks to protect natural-heritage values by imposing a blanket ban on certain activities, while customary community approaches towards conservation focus instead on reinstating and recalibrating relationships of exchange with a more-than-human nature (even appropriating state mechanisms to do so).

Customary communities in Timor-Leste have a long history of colonial (and now post-colonial) relations that continue to shape understandings of, and approaches to, their more-than-human relations. In the indigenous commitment to the recognition of these diverse relationships, 'the resonances as well as contradictions between different ontological styles are being recognized and new forms of order explored' (Salmond 2014:303). At this time, it remains unclear to what extent customary pathways for governance will substantively influence, modify, or even transform existing models of state governance. What is clear is that the ability to combine formal state and customary approaches to governance depends on the capability of all actors to embrace a meshwork of practices that, in its continuous becoming, forms the negotiated outcome of multiple, diverse, contingent flows and constraining elements. As we have 
seen above, when tara bandu processes are controlled less by communities and more by the state apparatus, such processes risk losing their generative qualities and constraining elements (presences, absences, blockages, bans, restrictions) and become fixed orders rather than continually negotiated outcomes. Yet, despite this, what anchors these tara bandu practices in an expanding meshwork over time and in place is their continued salience for the majority of Timor-Leste's diverse indigenous populations. Across the rural spectrum (and, to a lesser degree, in urban areas), localized relations with spirit ecologies and their associated ritual practices are understood to be essential to the pursuit of group and house-based intergenerational wellbeing. We recognize that customary relations are always of necessity, embedded in a knotted meshwork of flux as emergent processes across multiple bodies and times. It follows that the transformation and the renegotiation of power and ritual-political structures in post-conflict Timor-Leste are driven as much by Timorese commitments to honour their spirit ecologies as they are by the state-sanctioned intentions to harness or subvert their potential.

\section{Acknowledgements}

Fieldwork and research was supported by funding through two Australian Research Council Grants (DP160104519 and DP1095131). The authors also wish to acknowledge and thank the anonymous reviewers for their helpful comments on earlier versions of this article. All errors and omissions are ours.

\section{References}

Allerton, C. (2013). Potent landscapes: Place and mobility in eastern Indonesia. Honolulu: University of Hawai'i Press.

Arnhem, K. and G. Sprenger (eds) (2016). Animism in Southeast Asia. London and New York: Routledge.

Barnes, S. (2011). 'Origins, precedence and social order in the domain of Ina Ama Beli Darlari', in: A. McWilliam and E. Traube (eds), Land and life in Timor-Leste: Ethnographic essays, pp. 24-46. Canberra: ANU E Press.

Belun and The Asia Foundation (2013). Tara Bandu: Its role and use in community conflict prevention in Timor-Leste, Dili. https://asiafoundation.org/resources/pdfs/ TaraBanduPolicyBriefENG.pdf (accessed 22 July 2019).

Blaser, M. (2016). 'Is another cosmopolitics possible?', Cultural Anthropology 31-4:54570. 
Bovensiepen, J.M. (2015). The land of gold: Post-conflict recovery and cultural revival in independent Timor-Leste. Ithaca, NY: Cornell Southeast Asia Program Publications.

Carvalho, D., L. Palmer, A. Delimas, and P. Vieira (2008). 'Konserva natureza liu husi Tara Bandu'. [Report prepared for Concern, Dili.]

Cullen, A. (2016). Transitional environmentality: Conservation as territoriality in TimorLeste. [Phd thesis, University of Melbourne, Melbourne].

da Costa, C., A. da Costa Guterres, and J. Lopes (eds) (2006). Exploring Makassae culture. Baucau: Publicacoes Matebian-Grafica Diocesana Baucau.

Damaledo, A. (2018). Divided loyalties: Displacement, belonging and citizenship among East Timorese in West Timor. Canberra: ANU Press.

Edwards, J.G. (1970). 'The Koro pattern of depersonalization in an American schizophrenic patient', Journal of American Psychiatry 126-8:165-8.

Fitzpatrick, D., A. McWilliam and S. Barnes (2012). Property and social resilience in times of conflict: Land, custom and law in East Timor. London: Ashgate.

Fox, J.J. (1980). 'Models and metaphors: Comparative research in eastern Indonesia', in: J.J. Fox (ed.), The flow of life: Essays on eastern Indonesia, pp. 327-33. Cambridge, MA: Harvard University Press.

Fox, J.J. (ed.) (1997). The poetic power of place: Comparative perspectives on Austronesian ideas of locality. Canberra: ANU Press.

Fox, J.J. (2011). 'The articulation of tradition in Timor-Leste', in: A. McWilliam and E.G. Traube (eds), Land and life in Timor-Leste: Ethnographic essays, pp. 241-5o. Canberra: ANU E Press.

Fox, J.J. and D. Babo Soares (2000). Out of the ashes: Destruction and reconstruction of Timor-Leste. Canberra: ANU E Press.

Gombay, N. (2014). ' "Poaching”-What's in a name? Debates about law, property, and protection in the context of settler colonialism', Geoforum 55:1-12.

Henley, D. and J. Davidson (2008). 'In the name of adat: Regional perspectives on reform, tradition, and democracy in Indonesia', Modern Asian Studies 42-4:815-45.

Hicks, D. (2008). 'Glimpses of alternatives - the Uma Lulik of Timor-Leste', Social Analysis $5^{2-1: 166-88 . ~}$

Ingold, T. (2011). Being alive: Essays on movement, knowledge and description. London: Routledge.

Ingold T. (2012). 'Toward an ecology of materials', Annual Review of Anthropology 41: 427-42.

Jackson S. and L. Palmer (2012). 'Modernising water: Articulating custom in water governance in Australia and Timor-Leste', International Journal of Indigenous Policy $3^{-}$ 3:1-24.

Keane, W. (2007). Christian moderns: Freedom and fetish in the mission encounter. Berkeley, ca: University of California Press.

Lansing, S. (2007). Priests and programmers: Technologies of power in the engineered 
landscape of Bali. Rev. 2nd ed. Princeton, NJ; Oxford: Princeton University Press. [First published 1991.]

Li, T.M. (2008). The will to improve: Governmentality, development, and the practice of politics. Duke: Duke University Press.

McWilliam, A.R. (2005). 'Houses of resistance in Timor-Leste: Structuring sociality in the new nation', Anthropological Forum 15:27-44.

McWilliam, A.R. (2008). 'Fataluku healing and cultural resilience in Timor-Leste', Ethnos 73:217-40.

McWilliam, A.R. (2011). 'Fataluku living landscapes', in: A.R. McWilliam and E.G. Traube (eds), Land and life in Timor-Leste: Ethnographic essays, pp. 61-86. Canberra: ANU EPress.

McWilliam A.R. (2019). 'Stone archives and fortified histories in Timor-Leste', The Asia Pacific Journal of Anthropology (TAPJA) 39-1:247-6o.

McWilliam, A.R, L. Palmer and C. Shepherd (2014). 'Lulik encounters and cultural frictions in Timor-Leste: Past and present', The Australian Journal of Anthropology 253:300-20.

Meitzner Yoder, L. (2005). Custom, codification, collaboration: Integrating the legacies of land and forest authorities in Oecusse Enclave, Timor-Leste. [PhD thesis, Yale University, New Haven, Connecticut.]

Meitzner Yoder, L.S. (2007a). 'Hybridising justice: State-customary interactions over forest crime and punishment in Oecusse, Timor-Leste', The Asia Pacific Journal of Anthropology 8-1:43-57.

Meitzner Yoder, L.S. (2007b). 'The tobe and tara bandu: A post-independence renaissance of forest regulation authorities and practices in Oecusse, Timor-Leste', in: R. Ellen (ed.), Modern crises and traditional strategies: Local ecological knowledge in Island Southeast Asia, pp. 220-37. New York: Berghahn.

Mitchell, D. (2003). 'Shrinking penis disease', Inside Indonesia 75 (July-September). https://www.insideindonesia.org/shrinking-penis-disease (accessed 22 July 2019)

Myat Thu, P. (2008). 'Land forgotten: Effects of Indonesian re-settlement on rural livelihoods in Timor-Leste', in: D. Mearns (ed.), Democratic governance in Timor-Leste: Reconciling the local and the national, pp. 143-59. Darwin: CDU Press.

Palmer, L. (2007). 'Developing Timor Leste: Recognising the role of custom and tradition, Timor Leste. Proceedings from the Forum, 15 September 2006, pp. 35-40. Melbourne: SSEE. [Research Paper No. 1, University of Melbourne.]

Palmer, L. (2015). Water politics and spiritual ecology: Custom, environmental governance and development. London: Routledge. [Routledge Explorations in Environmental Studies.]

Palmer, L. (2018). 'Negotiating "darkness" and "light": Meshworks of fluidity and fire in Baucau', in: Judith Bovensiepen (ed.), Beyond the resource curse: Visions of the future in Timor-Leste after independence, pp. 189-204. Canberra: ANU Press. 
Palmer, L. and D.A. Carvalho (2008). 'Nation building and resource management: The politics of "nature" in Timor-Leste', Geoforum 39:1321-32.

Palmer, L., S. Barnes and R. Kakuma (2017). 'Opening the paths to healing: Developing an integrated approach to health in Timor Leste', in: 'What Witchcraft is this?' Global Encounters Between Development, Magic and Spiritual Ontologies, special issue, Third World Thematics 2-2/3:248-62.

Palmer, L. and A. McWilliam (2018). 'Ambivalent "indigeneities" in an independent Timor-Leste: Between the customary and national governance of resources', Asia Pacific Viewpoint 59-3:265-75.

Pannell, S. and S. O'Connor (2005). 'Toward a cultural topography of cave use in East Timor: A preliminary study', Asian Perspectives 44-1:193-206.

Paris, R. (2004). At war's end, building peace after civil conflict. Cambridge: CUP.

Salmond, A. (2014). 'Tears of Rangi: Water, power, and people in New Zealand', HAU: Journal of Ethnographic Theory 4-3:285-309.

Schram, R. (2007). "Sit, cook, eat, full stop": Religion and the rejection of ritual in Auhelawa (Papua New Guinea)', Oceania 77-2:172-9o.

Shepherd, C. (2013). Development and the environment in Timor-Leste. London: Routledge.

Shepherd, C. and L. Palmer (2015). 'The modern origins of traditional agriculture: Colonial policy, swidden development and environmental degradation in eastern Timor', South East Asian Journal of Humanities and Social Sciences 171-2/3:281-311.

Silva, K. (2013). 'Negotiating tradition and nation: Mediations and mediators in the making of urban Timor-Leste', The Asia Pacific Journal of Anthropology 14:45570 .

Silva, K. (2016). 'Administrando pessoas, recursos e rituais: Pedagogia economica como tatica de governo em Timor-Leste', Horizontes Antropologicos 22-45:127-53.

Strathern, A. and P. Stewart (2002). The python's back: Pathways of comparison between Indonesia and Melanesia. Connecticut and London: Bergin and Garvey.

Strathern, M. (2014). 'Anthropological reasoning: Some threads of thought', Hau: Journal of Ethnographic Theory 4-3:23-37.

Trindade, J. (2008). 'Reconciling conflicting paradigms: A Timor-Leste vision of an ideal state', in: D. Mearns (ed.), Democratic governance in Timor-Leste:Reconciling the local and the national, pp. 16o-88. Darwin: CDU Press.

Tsing A.L. (2005). Friction: An ethnography of global connection. Princeton: Princeton University Press.

Tsintjilonis, D. (2004). 'The flow of life in Buntao: Southeast Asian animism reconsidered', Bijdragen tot de Taal-, Land- en Volkenkunde 16o-4:425-55.

Wiyono, G. (2001). 'Timor Revival: A historical study of the Great Twentieth-Century Revival in Indonesia', Asian Journal of Pentecostal Studies 4-2:269-93.

Zerner, C. (1994). 'Through a green lens: The construction of customary environmental 
law and community in Indonesia's Maluku islands', Law \& Society Review 28-5:10791122.

Zerner C. (2003). 'Introduction; Moving translations: Poetics, performance and property in Indonesia and Malaysia', in: C. Zerner (ed.), Culture and the question of rights: Forests, coasts and seas in Southeast Asia, pp. 1-23. Durham: Duke University Press. 